\title{
Neuropathic Pain
}

National Cancer Institute

\section{Source}

National Cancer Institute. Neuropathic Pain. NCI Thesaurus. Code C96210.

Chronic pain caused by damage to nerve fibers. It is usually associated with tissue injury. 